\title{
Kemampuan Adaptasi Orang Kidal terhadap Lingkungan Non Kidal dalam Aktivitas Menulis dan Menggambar (Studi Kasus: Mahasiswa/i FSRD-ITB)
}

\author{
Andi Abdulqodir ${ }^{1}$, Andar Bagus Sriwarno ${ }^{2}$ \& Budi Isdianto ${ }^{3}$ \\ ${ }^{1}$ Magister Desain FSRD, Institut Teknologi Bandung, \\ Jl. Ganesa 10, Bandung 40132, Indonesia \\ ${ }^{2}$ KK. Manusia dan Desain Produk Industri FSRD, Institut Teknologi Bandung, \\ Jl. Ganesa 10, Bandung 40132, Indonesia \\ ${ }^{3}$ KK. Manusia dan Ruang Interior FSRD, Institut Teknologi Bandung, \\ Jl. Ganesa No.10 Bandung 40132, Indonesia \\ Email: qodeerwhite@yahoo.co.id
}

\begin{abstract}
Abstrak. Dalam dunia yang dihuni oleh mayoritas orang-orang non-kidal, orang-orang kidal terkenal dengan kemampuan beradaptasi terhadap barangbarang yang diperuntukkan bagi orang non kidal, seperti salah satunya kursi kuliah. Sedikitnya penelitian yang pernah dilakukan, memicu pada penelitian yang lebih jauh tentang kemampuan adaptasi populasi orang kidal. Penelitian ini bertujuan untuk mengidentifikasikan perilaku orang kidal terutama mengenai produktivitas, kemampuan adaptasi, orientasi gerak, dan tingkat kenyamanan selama mengerjakan tugas menulis dan menggambar. Dilakukan observasi visual untuk memperhatikan gerakan tertentu pada setiap tugas yang dilakukan di atas meja tulis biasa dan kursi kuliah. Penelitian dilakukan pada 14 responden, yang terdiri dari 7 responden kidal dan 7 responden non kidal. Semua responden merupakan mahasiswa aktif Fakultas Seni Rupa dan Desain ITB. Data yang terekam oleh video dianalisis dengan menggunakan perangkat lunak Image $J$ dengan pemisahan data video tersebut ke dalam beberapa bingkai (frame). Selain itu, responden juga diberikan kuesioner dengan menggunakan metode Visual Analog Scale (Semantic Differential) sebagai verifikasi dari data yang diperoleh dari observasi visual. Hasilnya menunjukkan bahwa tingkat kemampuan adaptasi orang kidal secara signifikan lebih tinggi daripada kemampuan adaptasi orang non-kidal dalam kasus perubahan situasi kerja. Hasil dari penelitian ini dirumuskan sebagai referensi pengembangan desain dari perangkat kerja bagi orang kidal agar sesuai dengan ketentuan desain universal.
\end{abstract}

Kata kunci: adaptasi; kidal; menulis; menggambar.

Abstract. In the world of right handed person (RHP) life, left handed person (LHP) is known to show their ability in adapting right handed-purpose goods such as table top chair in the classroom. The less number of researches lead this study to investigate in-depth about the adaptability of LHP population. This study aims to identify LHPs behavior according to their productivity, adaptability, movement orientation and comfort level during conducting writing and drawing tasks. Visual observation is conducted to determine the typical

Received September $3^{\text {rd }}, 2012$, Revised Desember $18^{\text {th }}, 2013$, Accepted for publication January $7^{\text {th }}, 2014$.

Copyright () 2014 Published by LPPM ITB, ISSN: 1978-3078, DOI: 10.5614/itbj.vad.2014.6.1.5 
movement during the tasks that done on the common table and table-top chair. 14 subjects were employed in this experiment that consist 7 LHP and 7 RHP. All subjects are students of Faculty of Arts and Design. Data recorded from video is analyzed by ImageJ software by splitting video data into images frame. To verify data gained from visual observation, visual analog scale method (Semantic Differential) was used to clarify all responds from subjects. The results of experiments showed that the level of LHP adaptability significantly higher than RHP in term of workstation changes. The result of this study is formulated to contribute the design improvement of workstation for LHP regarding universal design issues.

Keywords: adaptation; left handers; writing activity; drawing activity.

\section{$1 \quad$ Pendahuluan}

Tangan merupakan bagian tubuh yang melakukan aktivitas kerja kontrol berbeda dengan kaki yang berfungsi sebagai kendali (mobilitas). Tangan merupakan bagian yang paling penting dalam menunjang aktivitas sehari-hari. Rigal [1] menyebutkan bahwa aktivitas tangan dapat diklasifikasikan kedalam enam kategori yaitu, menggapai/menggenggam, mengoperasikan peralatan, melempar, mengangkat, menunjuk, dan aktivitas dengan menggunakan kedua tangan (bimanual activities). Dalam aktivitas normal sehari-hari tangan kanan merupakan tangan yang dominan untuk mengoperasikan produk. Perangkatperangkat pendukung kerja seperti produk rumah tangga, peralatan kantor, dan peralatan lainnya diposisikan untuk tangan kanan sebagai tangan yang superior dan tangan kiri sebagai yang inferior. Bagaimana dengan orang yang menggunakan tangan kiri sebagai tangan yang lebih dominan? Berdasarkan penelitian Strien [2] menyebutkan bahwa kemampuan tangan seseorang dibagi menjadi tiga yaitu, kidal (kiri), non kidal (kanan), dan ambidexter (mampu keduanya).

Orang yang kidal memang memiliki populasi yang sedikit $( \pm 10 \%$ dari populasi) dibandingkan orang yang beraktivitas dengan tangan kanan sehingga beberapa desain umumnya diperuntukkan dan digunakan untuk orang-orang non kidal. Orang kidal dalam hal ini harus beradaptasi terhadap perangkat/produk yang khusus digunakan untuk tangan kanan seperti gunting, mouse, penggaris, gas (motor), stir mobil, peralatan musik (gitar, bass, dan drum). Walaupun dalam hal ini terdapat pula produk yang digunakan secara universal baik kanan maupun kiri. Orang yang kidal pada akhirnya belajar untuk mencoba lebih sering dengan menggunakan tangan yang inferiornya (kanan) dibanding orang bertangan kanan menggunakan tangan inferiornya (kiri).

Dalam Beberapa penelitian dapat diketahui bahwa orang yang kidal dapat terbiasa dengan aktivitas yang dikhususkan untuk orang non kidal dan dapat 
dikatakan bahwa orang yang kidal dapat menjadi superior dibanding dengan orang yang non kidal [3-5].

Menulis merupakan salah satu aktivitas sehari-hari yang melibatkan tangan dengan gerakan yang konstan. Tentunya hal ini membutuhkan ketahanan atau tingkat stamina otot tangan yang tinggi yang dapat ditunjang oleh faktor kenyamanan. Dapat diketahui proses menulis orang kidal cenderung mendorong dan non kidal cenderung menarik. Ini menjadi pertanyaan apakah aktivitas menulis orang kidal merupakan pencerminan orang non kidal? Bagaimana fasilitas menulis bagi orang kidal sama dengan orang non kidal? Bagaimana tingkat adaptasi mereka saat menggunakan objek non kidal seperti kursi kuliah? Untuk melihat kecenderungan menulis ini maka penelitian mengenai fasilitas menulis dilakukan. Penelitian ini menggunakan dua objek desain yang terdiri dari meja biasa dan kursi kuliah. Selain meneliti mengenai menulis, penelitian ini mencoba membandingkan aktivitas menggambar dimana aktivitas ini bertujuan untuk mengetahui tingkat kenyamanan gerak tangan secara mendorong dan menarik antrara kidal dan non kidal. Selanjutnya variabelvariabel tersebut dikomparasikan sehingga mendapatkan tingkat produktivitas, adaptasi, dan kenyamanan antara kedua kategori kemampuan tangan tersebut.

\section{$2 \quad$ Metode}

Penelitian ini dilakukan secara kuantitatif dimana proses pengolahan data dilakukan secara statistik. Teknik pengumpulan data dilakukan dengan cara eksperimen dan kuesioner. Selanjutnya pengolahan data ini akan dijelaskan dan dianalisis secara deskriptif untuk mengetahui hasil dari penelitian tersebut. Variabel yang akan digunakan adalah Hubungan kenyamanan dengan tingkat produktivitas dan kemampuan adaptasi orang kidal saat aktivitas menulis di kursi kuliah dan dibandingkan dengan meja biasa. Untuk memperoleh data yang signifikan terhadap kenyamanan orang kidal dan orientasi arah menulis maka penelitian ini pula menggunakan responden non kidal sebagai pembanding/ komparasi.

Populasi yang menjadi subjek penelitian berada di kawasan Kota Bandung dan sekitarnya dan diambil beberapa sampel. Sampel yang diteliti adalah Mahasiswa Fakultas Seni Rupa dan Desain ITB (FSRD-ITB) yang memiliki kemampuan menggunakan tangan kiri atau tangan kanan. Responden terdiri dari 7 responden kidal dan 7 responden non kidal dimana terdapat 2 responden kidal dan 1 responden non kidal adalah wanita. Pengkategorian kemampuan tangan menggunakan kuesioner Coren [6], responden berusia antara 18-22 tahun, dimana pada usia ini tergolong usia produktif. 
Eksperimen dilakukan didokumentasikan dengan posisi kamera tegak lurus terhadap meja/kursi (Lihat Gambar 1). Pada meja dan kursi diletakan grid dengan skala $5 \mathrm{~cm}$ dan pada responden ditempelkan reference point berupa stiker yang diletakan pada sendi telunjuk, ibu jari, pergelangan, sikut, bahu aktif, pundak, dan bahu pasif. Reference point tersebut digunakan untuk dapat dihitung pergeserannya menggunakan perangkat lunak Image $J$ sehingga menghasilkan data kordinat $\mathrm{x}, \mathrm{y}$ dalam satuan piksel.

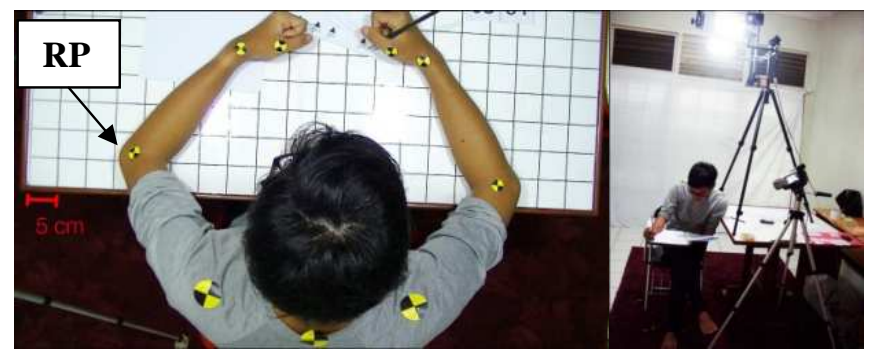

(i)

(ii)

Gambar 1 Eksperimen Tahapan Prosedur Perhitungan Data: (i) Penggunaan Reference Point (RP) dan Grid Meja dan (ii) Suasana Eksperimen dengan menggunakan Video Recorder. (Dok. Pribadi)
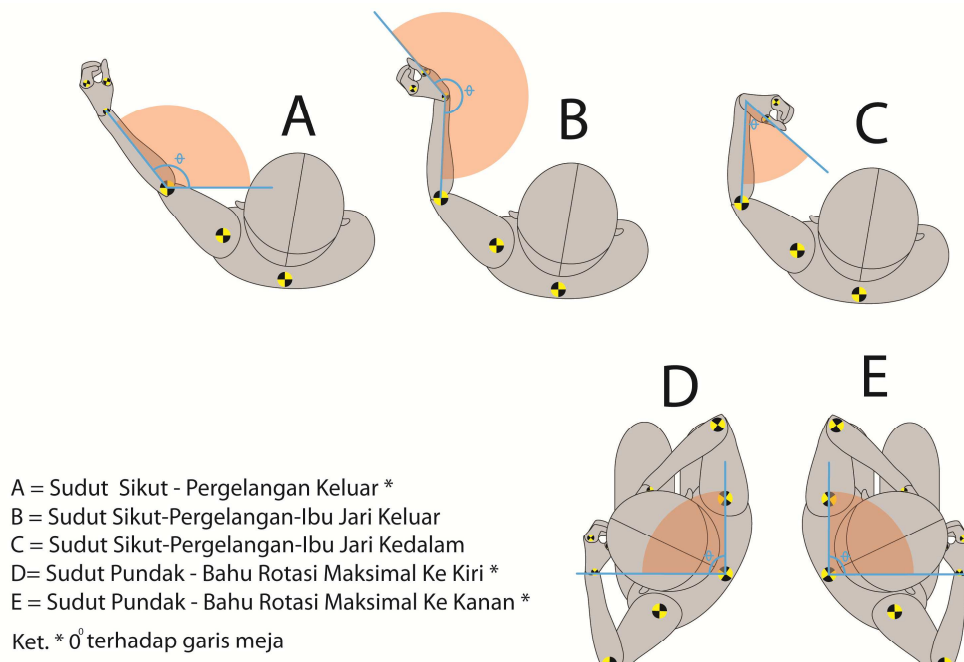

A = Sudut Sikut - Pergelangan Keluar * $B=$ Sudut Sikut-Pergelangan-Ibu Jari Keluar $C=$ Sudut Sikut-Pergelangan-Ibu Jari Kedalam $\mathrm{D}=$ Sudut Pundak - Bahu Rotasi Maksimal Ke Kiri * $\mathrm{E}=$ Sudut Pundak - Bahu Rotasi Maksimal Ke Kanan * Ket. * $0^{0}$ terhadap garis meja

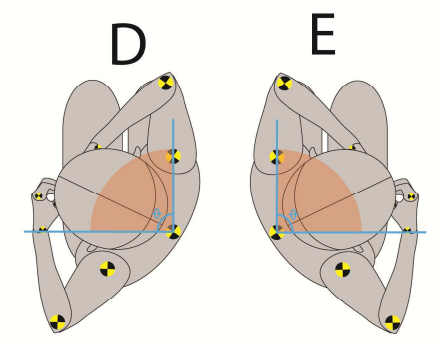

Gambar 2 Range of Motion.

Selanjutnya peneliti melakukan perhitungan Range of Motion (ROM) dari pergerakan maksimum sebelum melakukan eksperimen (Lihat Gambar 2). Ini 
dilakukan untuk mengetahui gerak maksimum pergerakan sudut tiap sendi yang nantinya akan dikomparasi dengan gerak produktif saat melakukan eksperimen (Lihat Gambar 3).

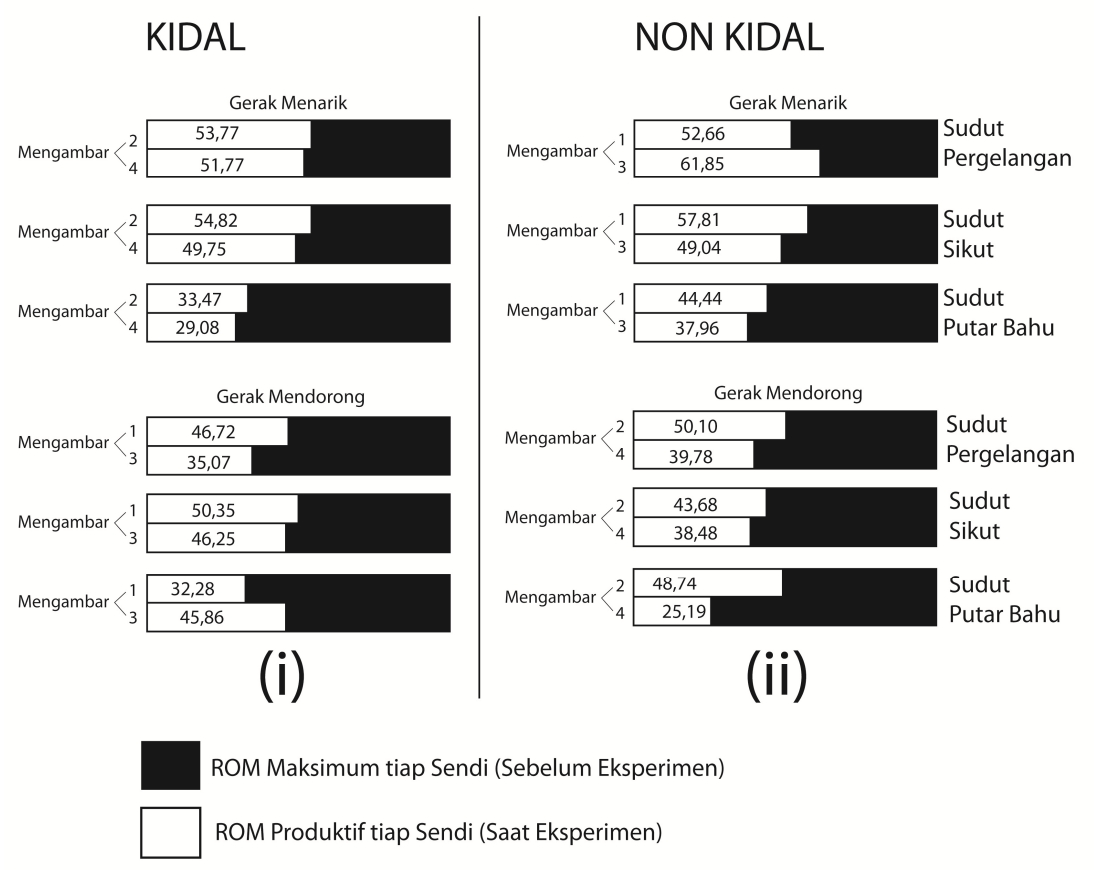

Gambar 3 Presentase Perbandingan ROM Maksimum dan ROM Produktif Antara (i) Kidal dan (ii) Non Kidal.

Eksperimen terdiri dari 4 jenis eksperimen diantaranya:

1. Menggambar 1 dan 3, yaitu menggambar pola dari kiri ke kanan

2. Menggambar 2 dan 4 , yaitu menggambar pola dari kanan ke kiri

3. Menulis 1 dan 3, yaitu menyalin teks dengan posisi kertas dibebaskan senyaman mungkin, dan

4. Menulis 2 dan 4, yaitu menyalin teks dengan posisi kertas tegak lurus.

Dalam aktivitas menggambar terdapat istilah gerakan menarik dan mendorong. Gerakan menarik merupakan gerakan tangan dari kanan ke kiri bagi responden kidal dan gerakan tangan dari kiri ke kanan bagi responden non kidal. Sebaliknya untuk gerakan mendorong merupakan gerak tangan dari kiri ke kanan bagi responden kidal dan gerakan dari kanan ke kiri bagi responden non kidal. Keempat eksperimen ini dilakukan di dua objek desain yang berbeda yaitu meja biasa dan kursi kuliah. Setelah melakukan tiap eksperimen 
responden mengisi dua parameter yaitu Semantic Diferential Technique (SDT) dan Kuesioner Corlett yang telah dimodifikasi dalam pembagian tubuhnya.

Data yang telah terkumpul terutama data eksperimen dianalisis dengan pengolahan data statistik dari beberapa variabel dengan menggunakan Paired T-Test $(\mathrm{p}<0,05)$ Komparasi kedua responden dilihat dari tingkat efisiensi, efektivitas dan adaptasi serta kenyamanan saat menggunakan meja biasa dan kursi kuliah. Data hasil kuesioner dan eksperimen dijelaskan secara deskriptif. Penggunaan perangkat lunak StatView, Image $J$ dan Pengembangan programming animasi pergerakan tangan digunakan untuk mempermudah mengkuantifikasi dan menganalisis data.

\section{$3 \quad$ Eksperimen dan Analisis}

Produktivitas dalam bekerja dapat dilihat dari efektivitas dan efisiensi yang terukur dalam parameter waktu. Semakin rendah waktu yang dikerjakan dalam sebuah aktivitas maka semakin tinggi produktivitasnya. Responden terdiri dari 57\% responden kidal dengan kemampuan tangan kiri yang kuat dan $71 \%$ responden non kidal dengan kemampuan tangan kanan yang kuat [6].

Dalam penelitian terjadi performa yang sama antara kidal dan non kidal ini dilihat dari parameter waktu yang tidak signifikan ( $>>0,05)$ (Lihat Gambar Tabel 1). Dapat dianalisis bahwa tingkat produktivitas responden kidal cenderung sama dengan responden non kidal atau bahkan dapat dikatakan produktivitas orang kidal lebih tinggi dikarenakan mereka berada dalam kondisi menulis yang tidak mendukung secara fisiologi. Sebaliknya responden non kidal berada dalam kondisi yang menguntungkan secara fisiologi terutama untuk menulis. Dari beberapa eksperimen yang dilakukan dapat dikatakan bahwa responden kidal cenderung dominan (superior) dibandingkan dengan non kidal (inferior), ini memperkuat teori-teori pada penelitian mengenai kidal sebelumnya.

Tabel 1 P-Value Eksperimen Perbandingan Waktu Antara Kidal dan Non Kidal.

\begin{tabular}{lc}
\hline Eksperimen & P-Value \\
\hline Menggambar 1 & 0,3779 \\
Menggambar 2 & 0,8016 \\
Menulis 1 & 0,6955 \\
Menulis 2 & 0,5351 \\
Menggambar 1 & 0,7907 \\
Menggambar 2 & 0,6805 \\
Menulis 3 & 0,3796 \\
Menulis 4 & 0,3899 \\
\hline
\end{tabular}


Aktivitas menulis dan menggambar orang kidal maupun non kidal memiliki beberapa variasi gerak. Variasi gerak terjadi disebabkan oleh pola kebiasaan yang berbeda tiap orang yang dipengaruhi oleh beberapa faktor baik internal maupun eksternal. Dalam aktivitas menulis bagi orang kidal pada umumnya beradaptasi dengan bergerak memutar atau mengeserkan badan ini dikarenakan kompensasi gerak tangan dari kiri ke kanan yang mengharuskan badan bergerak untuk memperluas jangkauan gerak. Hal ini berbeda dengan orang non kidal yang sedikit menggerakan tubuh saat melakukan aktivitas menulisnya dikarenakan kondisi sikut yang dijadikan sebagai sumbu putar saat menulis dari kiri ke kanan sehingga kompensasi gerak tubuh menjadi kecil.

Walaupun dalam menulis dan menggambar orang kidal terutama dengan arah dari kiri ke kanan menyebabkan gerak putar terutama pada bagian pergelangan, sikut, bahu dan pelvis. Hal ini tidak menyebabkan keletihan yang tinggi apabila dibandingkan dengan orang non kidal dalam aktivitas yang sama dan bahkan orang non kidal saat menulis lebih kecil tingkat gerak putar pada sendi terutama pada sikut, bahu dan pelvis. Hal ini dikarenakan perputaran sikut yang efisien sebagai penggerak saat menulis.

Dalam aktivitas menggambar dari kanan ke kiri pada meja biasa terjadi nilai yang signifikan $(\mathrm{p}<0,05)$ dimana responden non kidal mengalami ketidaknyamanan saat melakukan gerak mendorong dan ini tidak terjadi pada responden kidal saat melakukan aktivitas menggambar dari kiri ke kanan (mendorong)

Pola Adaptasi yang telah dijelaskan sebelumnya dimana terdapat berbagai variasi menulis dan mengambar yang terjadi pada orang kidal dan non kidal, berpengaruh pada kemiringan kertas. Kemiringan kertas pada responden kidal cenderung berada pada posisi kemiringan kertas yang menurun sebaliknya pada orang non kidal kemiringan kertas lebih naik. Namun responden kidal cenderung berada dikondisi kertas yang tegak lurus. Hal ini berpengaruh terhadap bentuk dari meja terutama pada alas kursi kuliah. Dapat dianalisis bahwa semakin miring posisi kertas maka semakin rendah pergerakan sikut, ini dikarenakan kemiringan tersebut sejajar dengan perputaran tangan yang cenderung miring. Apabila kemiringan kertas tegak lurus terhada meja maka dapat mengakibatkan pergerakan sikut yang tinggi.

Pergerakan sudut digunakan untuk mengetahui apakah sendi tersebut melakukan flexion atau extension/internal rotation atau external rotation. Semakin tinggi percepatan derajat sudut tiap sendi maka dapat disimpulkan bahwa gerakan sendi lebih banyak melakukan extension/external rotation atau sebaliknya apabila sendi lebih banyak melakukan percepatan derajat yang lebih rendah maka sendi lebih banyak melakukan flexion/internal rotation. Dari hasil 
data menunjukan bahwa percepatan sudut antara kidal non kidal cenderung berbanding terbalik dimana responden kidal cenderung melakukan extension/ internal rotation maka responden non kidal cenderung melakukan flexion/ external rotation. Sudut yang berbanding terbalik ini dapat disimpulkan bahwa responden kidal dan non kidal saat menulis dan menggambar melakukan gerak otot yang berbeda.

Pada eksperimen mengambar 1 dan 3 dimana responden kidal melakukan gerak mendorong dan responden non kidal melakukan gerak menarik, dapat dilihat terjadi presentase yang berbeda dimana responden kidal cenderung memiliki ROM Produktif lebih kecil dibandingkan dengan responden non kidal (lihat Gambar 3). Sebaliknya pada eksperimen menggambar 2 dan 4 dimana responden kidal melakukan gerak menarik dan responden non kidal melakukan gerak mendorong dapat dilihat terjadi ROM produktif dimana kidal memiliki presentase yang lebih besar dibandingkan dengan responden non kidal. Hal ini diartikan bahwa saat responden melakukan gerak mendorong baik kidal maupun non kidal memiliki ROM produktif yang presentase geraknya kecil dibandingkan saat melakukan gerak mendorong. Perubahan sudut tiap sendi saat mendorong berada dikondisi gerak minimum apabila dibandingkan dengan gerak menarik.

Kondisi gerak yang tidak netral terutama terjadi pada orang kidal saat menulis di kursi kuliah belum menunjukan tingkat ketidaknyamanan yang tinggi. Hal ini dilihat dari dua parameter yaitu SDT dan Kuesioner Corlett. Kedua Subjective Assessment tersebut menunjukan data yang tidak signifikan $(\mathrm{p}>0,05)$ antara orang kidal dan non kidal. Walaupun terjadi penurunan tingkat kenyamanan pada kuesioner Corlett namun keduanya memiliki kecenderungan yang hampir sama. Namun apabila dilihat secara lebih dekat terlihat bahwa responden kidal lebih dapat beradaptasi dikondisi yang kurang nyaman dibandingkan responden non kidal. Hal ini terjadi karena kondisi lingkungan non kidal yang mendominasi menyebabkan kebiasaan dalam beradaptasi menyebabkan orang kidal memiliki cakupan kenyamanan yang lebih luas dibandingkan dengan orang non kidal. Ini terlihat dari eksperimen menggambar dari kanan ke kiri yang secara fisiologi kurang menguntungkan bagi responden non kidal terjadi peningkatan ketidaknyaman. Berbeda dengan responden kidal yang sudah terbiasa dalam kondisi kurang menguntungkan saat menggambar dari kiri ke kanan.

Kondisi gerak yang tidak netral terutama terjadi pada orang kidal saat menulis di kursi kuliah belum menunjukan tingkat ketidaknyamanan yang tinggi. Hal ini dilihat dari dua parameter yaitu SDT dan Kuesioner Corlett. Kedua Subjective Assessment tersebut menunjukan data yang tidak signifikan $(\mathrm{p}>0,05)$ antara 
orang kidal dan non kidal. Walaupun terjadi penurunan tingkat kenyamanan pada kuesioner Corlett namun keduanya memiliki kecenderungan yang hampir sama. Namun apabila dilihat secara lebih dekat terlihat bahwa responden kidal lebih dapat beradaptasi dikondisi yang kurang nyaman dibandingkan responden non kidal. Hal ini terjadi karena kondisi lingkungan non kidal yang mendominasi menyebabkan kebiasaan dalam beradaptasi menyebabkan orang kidal memiliki cakupan kenyamanan yang lebih luas dibandingkan dengan orang non kidal. Ini terlihat dari eksperimen menggambar dari kanan ke kiri yang secara fisiologi kurang menguntungkan bagi responden non kidal terjadi peningkatan ketidaknyaman. Berbeda dengan responden kidal yang sudah terbiasa dalam kondisi kurang menguntungkan saat menggambar dari kiri ke kanan.

\section{$4 \quad$ Hasil dan Pembahasan}

Aktivitas menulis dan menggambar merupakan kegiatan yang pada umumnya sudah menjadi rutinitas umum. Bagi orang-orang non kidal kebiasaan tersebut sebagian besar telah diakomodasi melalui fasilitas yang memadai namun bagi orang kidal fasilitas yang khusus bagi aktivitas tangan yang berbeda sangatlah jarang. Pada akhirnya mereka harus beradaptasi dengan fasilitas/lingkungan non kidal. Penelitian ini dilakukan untuk mengetahui bagaiman perilaku menulis dan menggambar baik di meja biasa maupun di kursi kuliah. Kesimpulan umum dari penelitian ini adalah bahwa responden kidal cenderung adaptif dalam kondisi lingkungan non kidal. Adapun kesimpulan lebih terperinci, diantaranya adalah;

\subsection{Tingkat Produktivitas dan Kenyamanan}

Responden kidal memiliki tingkat produktivitas yang sama dengan responden non kidal. Tingkat produktivitas ini dapat dilihat dari waktu pengerjaan baik menulis maupun menggambar memiliki rata-rata pengerjaan yang relatif sama walaupun responden kidal merasa tidak diuntungkan saat melakukan aktivitas diatas kursi kuliah. Pada aktivitas menulis dan menggambar diatas meja biasa responden kidal dan non kidal memiliki tingkat produktivitas yang sama dan dikondisi tersebut responden kidal cenderung beraktivitas normal dimana perputaran tubuh diminimalisasikan.

Untuk tingkat kenyamanan secara subjektif menghasilkan output bahwa responden kidal cenderung memiliki tingkat kenyamanan yang sama saat melakukan aktivitas menulis dan menggambar. Namun dalam rata-rata aktivitas dapat dilihat bahwa terjadi hal yang sebaliknya dimana responden non kidal memiliki tingkat kenyamanan yang rendah apabila dibandingkan dengan responden kidal. Dalam aktivitas menulis dan menggambar responden kidal 
cenderung merasa tidak nyaman pada bagian lengan aktif namun pada responden non kidal dalam beberapa kasus, aktivitas tersebut mempengaruhi tingkat ketidaknyamanan pada bagian sisi tubuh pasif.

Faktor kenyamanan responden kidal pada saat eksperimen tidak mempengaruhi produktivitas kerja saat beraktivitas di meja dan kursi kuliah. hal ini dapat disimpulkan bahwa range kenyamanan responden kidal cenderung lebih tinggi dibandingkan responden non kidal sehingga terjadi perbedaan tingkat produktivitas.

\subsection{Tingkat Adaptasi}

Menulis dan menggambar dari kiri ke kanan memberikan kompensasi fisik bagi orang kidal untuk menggerakan alat tulis dengan cara mendorong. Berbeda dengan orang non kidal yang menggerakkan alat tulis dengan cara menarik. Namun kali ini faktor kebiasaan yang menciptakan tingkat adaptasi kidal lebih tinggi dibandingkan dengan non kidal dalam kondisi kurang menguntungkan secara fisik. Ini terbukti dari eksperimen menggambar pada meja biasa dimana responden non kidal mengalami kesulitan saat menarik garis dari kanan ke kiri yang secara kompensasi fisik kurang menuntungkan. Hal ini tidak terjadi pada responden kidal saat menarik garis dari kiri ke kanan. Dapat disimpulkan bahwa responden kidal sudah terbiasa dengan aktivitas mendorong saat menulis ataupun menggambar dikarenakan mereka berada dilingkungan non kidal yang dominan sehingga lingkungan mempengaruhi kemampuan adaptasi orang kidal.

\subsection{Orientasi Menulis}

Pergerakan orang kidal saat menulis mengharuskan mereka untuk melakukan gerak mendorong sehingga terjadi kompensasi fisik terutama pada bagian sikut. Pada umumnya orang kidal cenderung mengerakkan sikut dengan cara bergerak miring ke depan-kanan dimana pergerakkan tersebut mempengaruhi gerak badan untuk berputar atau bergeser. 1 dari 7 responden kidal memiliki orientasi gerak tangan saat menulis yang berbeda dimana posisi sikut dijadikan sumbu putar sehingga gerak tangan bergerak miring ke belakang-kanan. Hal ini menimbulkan kompensasi bagi tubuh untuk perlahan bergerak ke belakang dan mengurangi gerak fisik lain secara berlebihan. Namun dalam kasus ini mempengaruhi posisi kepala dan leher yang cenderung miring.

Pergerakan dari tubuh responden kidal dan saat beraktivitas di meja biasa cenderung normal. Walaupun responden kidal cenderung berputar kearah kiri dan responden non kidal cenderung berputar ke arah kanan. Selain dari pergerakkan tubuh, orientasi menulis dapat dilihat dari kemiringan kertas saat melakukan aktivitas. Kemiringan menulis antara kidal dan non kidal memiliki perbedaan yang signifikan dimana kemiringan kertas responden kidal cenderung 
menurun dan responden pengguna tangan kanan cenderung naik. Namun apabila dilihat dari aktivitas keseluruhan responden kidal cenderung menulis dalam posisi kertas yang tegak lurus dan responden non kidal lebih dominan di kondisi kemiringan kertas naik. Dalam hal ini dapat disimpulkan bahwa responden kidal lebih beradaptasi dikondisi menulis yang tegak lurus dibandingkan responden non kidal.

Dalam kesimpulan ini dapat dikatakan bahwa responden kidal bukan merupakan aktivitas mirror tangan kanan dalam menulis ataupun menggambar. Ini disimpulkan bahwa dalam mengaplikasikan kursi terutama kursi kuliah tidak dapat diselesaikan dengan hanya mencerminkan 'mirror' namun terdapat kemiringan yang berbeda antara kidal dan non kidal saat menulis dan menggambar. Untuk penggunaan meja biasa aktivitas gerak cenderung normal baik responden kidal maupun non kidal.

\subsection{Aplikasi Terhadap Desain}

Eksperimen ini menghasilkan beberapa rancangan umum terutama untuk responden kidal yang dapat dikembangkan kedalam desain. Adapun pengaplikasian pada penggunaan kursi kuliah yang diantaranya adalah:

1. Pada dasarnya pergerakan sikut responden kidal cenderung tinggi sehingga dapat menyebabkan kelelahan pada bagian bahu sebagai penggerak dari sikut. Dalam hal ini dibutuhkan penahan pada bagian sikut agar bagian tersebut dapat beristirahat sejenak saat melakukan aktivitas terutama menulis

2. Untuk penerapan kursi kuliah untuk orang kidal dibutuhkan tambahan yaitu;

a. Alas meja berbeda dengan alas meja untuk orang non kidal dimana untuk orang kidal alas meja pada bagian peletakan sikut haruslah lebih besar areanya dikarenakan pergerakan sikut yang tinggi. Gambar 4 merupakan alternatif dari penerapan kursi kuliah untuk kidal.

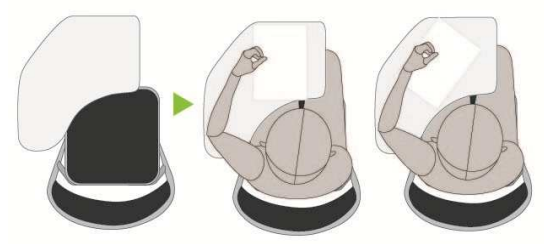

Gambar 4 Aplikasi Untuk Kursi Kuliah Alternatif 1.

b. Untuk dapat digunakan untuk kedua kategori kemampuan tangan, bangku kuliah dapat pula dipasangkan tempat duduk yang dapat berputar sehingga saat orang kidal menulis, mereka dapat memutarkan 
tubuh keseluruhan sehingga terhindari sikap tubuh tidak netral (Lihat Gambar 5). Pada alas kursi yang dapat memutar dibutuhkan pula penopang punggung yang pada bagian kiri sedikit melengkung. Ini digunakan untuk penopang bagi orang kidal saat memutarkan tubuh saat menulis.

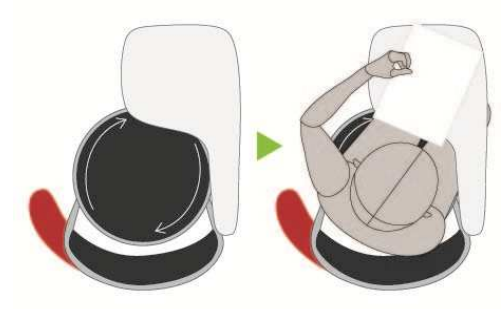

Gambar 5 Aplikasi Untuk Kursi Kuliah Alternatif 2.

c. Rekomendasi lainnya adalah memberikan tambahan alas meja pada bagian kanan (Lihat Gambar 6 dan 7). Untuk penggunaan tangan kiri, meja dapat diputar berlawanan jarum jam sehingga mendapatkan formasi bentuk baru.

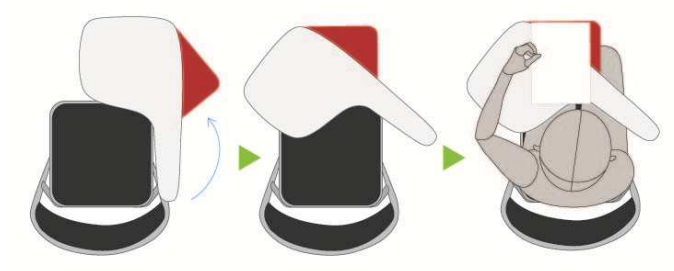

Gambar 6 Aplikasi Untuk Kursi Kuliah Alternatif 3.

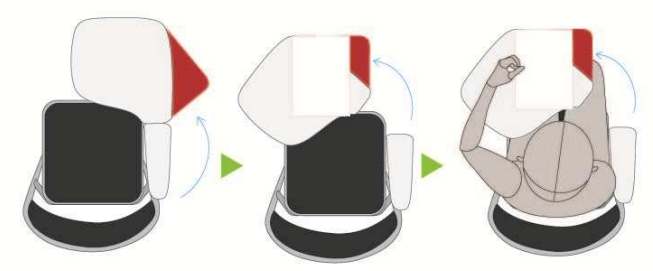

Gambar 7 Aplikasi Untuk Kursi Kuliah Alternatif 4.

Pengaplikasian diatas merupakan aplikasi teknis yang dapat dijadikan sebagai alternatif. Namun dalam hal ini terdapat sebuah wacana besar di dalam penelitian yang menyatakan bahwa responden kidal baik dalam lingkup penelitian maupun di Indonesia pada umumnya belum menjadi perhatian 
terutama dalam akses penggunaan produk. Lingkungan yang mayoritas non kidal menciptakan aktivitas kerja yang cenderung didominasi tangan kanan. Apabila sebuah perancangan desain harus dapat diakses oleh semua orang, dalam hal ini perlu penataan kembali tata ruang kerja dan pendataan perkembangan populasi kidal terutama di Indonesia.

\subsection{Evaluasi Eksperimen}

Dalam penelitian ini terdapat metode yang dapat dievaluasi kembali apabila dilakukan penelitian lanjutan. Adapun saran untuk penelitian lebih lanjut tersebut diantaranya:

1. Dalam menganalisis eksperimen hanya menggunakan analisis menulis dan menggambar dalam jangkauan 1 frame per detik (dalam data video) sehingga pergerakan tiap sendi akan lebih cepat yang dapat mengurangi analisis yang lebih signifikan. Hal ini dikarenakan data video dapat ditangkap dalam jangkauan 25 frame per detik.

2. Dalam penggunaan reference point yang ditempelkan pada baju dapat mengakibatkan pergeseran pada bagian tersebut. Pergeseran ini menyebabkan data yang diperoleh kurang valid walaupun pada dasarnya pergeseran cenderung sangat kecil.

3. Data analisis video dilakukan dengan memotong bagian analisis sehingga analisis tidak dilakukan hingga akhir aktivitas. Hal ini menyebabkan banyak analisis yang kemungkinan dapat dilakukan lebih lanjut untuk menemukan teori-teori baru.

4. Aktivitas menulis dilakukan diatas selembar kertas A4 $(29,7 \times 21 \mathrm{~cm})$ sehingga tingkat kesulitan cenderung rendah dikarenakan tidak ada ketebalan kertas. Untuk penelitian lanjutan dapat dilakukan diatas buku tulis sehingga ketebalan tersebut kemungkinan dapat mempengaruhi kenyamanan responden kidal.

5. Penelitian untuk tingkat keletihan dapat dilanjutkan dengan menggunakan elektromiografi sehingga data yang dihasilkan tidak hanya secara subjektif namun dapat disimpulkan secara objektif.

6. Aktivitas menulis dapat dikembangkan dengan variasi berbeda misalnya menulis dengan menggunakan tablet, menulis dengan posisi tegak lurus misalnya papan tulis, dan menulis dengan kemiringan alas tertentu.

7. Penggunaan workstation dalam situasi ujian saringan masuk terutama bagi mahasiswa kidal FSRD dapat menjadi pertimbangan untuk penelitian lebih lanjut dikarenakan pentingnya menciptakan kondisi tubuh yang netral bagi mereka saat ujian sehingga tercipta produktivitas yang seimbang baik kidal maupun non kidal. 


\section{$5 \quad$ Kesimpulan}

Penelitian ini memberikan kesimpulan dari beberapa pertanyaaan penelitian. Pertama, berkenaan dengan pencerminan antara kidal dan non kidal saat menulis dan menggambar dapat disimpulkan bahwa responden kidal bukan merupakan aktivitas mirror tangan kanan dalam menulis ataupun menggambar. Ini diartikan bahwa dalam mengaplikasikan kursi terutama kursi kuliah tidak dapat diselesaikan dengan hanya mencerminkan 'mirror' namun terdapat kemiringan yang berbeda antara kidal dan non kidal saat menulis dan menggambar. Adapun aplikasi terhadap kursi telah dijelaskan pada poin 4 mengenai aplikasi terhadap desain. Untuk penggunaan meja biasa aktivitas gerak cenderung normal baik responden kidal maupun non kidal. Kedua, berkenaan dengan fasilitas dalam beraktivitas antara kidal dan non kidal saat menulis dan menggambar dapat disimpulkan bahwa terdapat perbedaan fasilitas penunjang antara kidal dan non kidal terutama saat menulis dan menggambar. Perbedaan tersebut dapat dilihat dari orientasi menulis dan menggambar serta perubahan gerak tubuh. Ketiga, berkenaan dengan tingkat adaptasi terutama pada saat responden kidal dan non kidal menggunakan kursi kuliah terdapat dua jenis adaptasi yaitu adaptasi saat responden kidal menggunakan kursi kuliah yang dilihat dari range kenyamanan dan parameter waktu dan saat menggunakan alat tulis dengan cara mendorong. Adapun kesimpulannya bahwa range kenyamanan responden kidal cenderung lebih tinggi dibandingkan responden non kidal sehingga terjadi perbedaan tingkat adaptasi dan produktivitas. Ini membuktikan bahwa tingkat adaptasi responden kidal lebih tinggi dibandingkan dengan responden non kidal. Dari aktivitas menulis dengan cara mendorong dapat disimpulkan bahwa responden kidal sudah terbiasa dengan aktivitas mendorong saat menulis ataupun menggambar dikarenakan mereka berada dilingkungan non kidal yang dominan sehingga lingkungan mempengaruhi kemampuan adaptasi orang kidal.

\section{Referensi}

[1] Rigal, R.A. 1992. Which Handedness: Preference or Performence?, Perceptual and Motor Skill, 75, pp. 851-866.

[2] Van Strien, J.W. 2002. The Dutch Handedness Questionnaire. Article $F S W$, Department of Psychology, Erasmus University Rotterdam.

[3] Delisle, A., Imbeau, D., Santos, B., Plamondon, A. \& Montpetit, Y. 2004. Left-Handed versus Right-Handed Computer Mouse Use: Effect on Upper-Extremity Posture, Applied Ergonomics, 35, pp. 21-28.

[4] Hoffmann, R., Chang, W. \& Yim, K. 1997. Computer Mouse Operation: is The Left-Handed User Disadvantaged?, Applied Ergonomics, 28(4), p 245-248. 
[5] Schmauder, M., Eckert, R. \& Schindhelm, R.E.R. 1993; Chapanis, A. \& Gropper, B.A., 1968. Dalam Hoffmann, R. 1997. Movement Time of Right- and Left-Handers Using Their Preferred and Non-Preferred Hands, International Journal of Industrial Ergonomics, 19, pp. 49-57.

[6] Coren, S. 1992. The Left-Hander Syndrome: The Causes and Consequences of Left-Handedness, New York: A Division of Random House, Inc. 